\title{
Naming CRISPR alleles: endonuclease-mediated mutation nomenclature across species
}

\author{
Michelle N. Knowlton ${ }^{1}$ - Cynthia L. Smith ${ }^{1}[$
}

Received: 14 April 2017 / Accepted: 27 May 2017 / Published online: 6 June 2017

(c) The Author(s) 2017. This article is an open access publication

\begin{abstract}
The widespread use of CRISPR/Cas and other targeted endonuclease technologies in many species has led to an explosion in the generation of new mutations and alleles. The ability to generate many different mutations from the same target sequence either by homologydirected repair with a donor sequence or non-homologous end joining-induced insertions and deletions necessitates a means for representing these mutations in literature and databases. Standardized nomenclature can be used to generate unambiguous, concise, and specific symbols to represent mutations and alleles. The research communities of a variety of species using CRISPR/Cas and other endonuclease-mediated mutation technologies have developed different approaches to naming and identifying such alleles and mutations. While some organism-specific research communities have developed allele nomenclature that incorporates the method of generation within the official allele or mutant symbol, others use metadata tags that include method of generation or mutagen. Organism-specific research community databases together with organism-specific nomenclature committees are leading the way in providing standardized nomenclature and metadata to facilitate the integration of data from alleles and mutations generated using CRISPR/Cas and other targeted endonucleases.
\end{abstract}

Michelle N. Knowlton

michelle.knowlton@jax.org

1 Mouse Genome Informatics, The Jackson Laboratory, Bar Harbor 04609, USA

\section{Introduction}

The emergence of targeted endonucleases as a means for somatic and germline modification provides a versatile approach to mutagenesis and genetic engineering across species. Transcriptional activator-like effector nucleases (TALENs), zinc finger nucleases (ZFN), and clustered regularly interspaced short palindromic repeats with Cas9 nucleases (CRISPR/Cas9) have been successful in more than forty organisms, with uses spanning the creation of human disease models, essential basic research and commercial modifications to agricultural organisms (Table 1; reviewed in Harrison et al. 2014 and; Carroll 2014).

The use of CRISPR/Cas9 technology is quickly surpassing other methods for rapid generation of an array of single gene and multiplex mutations with minimal sequence constraints often associated with ZFN and TALENs (reviewed in Seruggia and Montoliu 2014). All three technologies induce targeted double-strand breaks that are repaired through either error-prone, non-homologous end joining (NHEJ) or homology-directed recombination (HDR) with a donor template depending on experimental conditions to produce a variety of mutations ranging from insertions and deletions to sequence replacement (Fig. 1; reviewed in Carroll 2014; Chen et al. 2014; Guha et al. 2017; Harrison et al. 2014). Thus, a single targeting sequence can produce an array of alleles from those containing a single-nucleotide deletion or insertion to alleles with large gene deletion $(65 \mathrm{~kb})$ or cassette insertion up to $5 \mathrm{~kb}$ (Zhang et al. 2015). The ability to generate so many mutations from a single targeting sequence makes CRISPR/Cas9 a powerful tool for reverse genetics, targeted allele generation, and reversion of existing mutation (reviewed in Guha et al. 2017). In addition, the number and diversity of mutations and alleles created presents a challenge to unambiguous identification, 
Table 1 Targeted endonucleases (CRISPR, TALEN, ZFN) have been used in many species to generate somatic and germline modifications in organisms

\begin{tabular}{|c|c|c|}
\hline Organism & Endonuclease targeting system & Reference \\
\hline \multicolumn{3}{|l|}{ Vertebrates } \\
\hline Axolotl & CRISPR, TALEN & Fei et al. (2014), Flowers et al. (2014) \\
\hline Catfish & CRISPR, TALEN, ZFN & Dong et al. (2011), Dong et al. (2014), Li M et al. (2016) \\
\hline Cattle & CRISPR, TALEN, ZFN & Wu et al. (2015), reviewed in Tang et al. (2015) \\
\hline Frog & CRISPR, TALEN, ZFN & Reviewed in Shi et al. (2017) \\
\hline Goat & CRISPR, TALEN & Reviewed in Menchaca et al. (2016) \\
\hline Medaka & CRISPR, TALEN, ZFN & Ansai and Kinoshita (2014), Guan et al. (2014), Wang and Hong (2014) \\
\hline Mouse & CRISPR, TALEN, ZFN & Reviewed in Sander and Joung (2014) \\
\hline Monkey & CRISPR, TALEN & Niu et al. (2014), Wan et al. (2015) \\
\hline Newt & TALEN & Hayashi T et al. (2014) \\
\hline Pig & CRISPR, TALEN, ZFN & Sato et al. (2014), reviewed in Tang et al. (2015) \\
\hline Rabbit & CRISPR, TALEN, ZFN & Flisikowska et al. (2011), Honda et al. (2015), Wang et al. (2014b) \\
\hline Rat & CRISPR, TALEN, ZFN & Reviewed in Mashimo T (2014) \\
\hline Rainbow trout & ZFN & Yano et al. (2012) \\
\hline Sheep & CRISPR, TALEN, ZFN & Reviewed in Menchaca et al. (2016), Zhang et al. (2016a, b, c) \\
\hline Tilapia & CRISPR, TALEN & Li et al. (2013a, b), Li et al. (2014) \\
\hline Zebrafish & CRISPR, TALEN, ZFN & Reviewed in Auer et al. (2014) \\
\hline \multicolumn{3}{|l|}{ Invertebrates } \\
\hline Butterfly & CRISPR, TALEN, ZFN & Market et al. (2016), Merlin et al. (2013) \\
\hline Cricket & CRISPR, TALEN, ZFN & Awata et al. (2015), Watanabe (2012) \\
\hline Freshwater flea & CRISPR, TALEN & Naitou et al. (2015), Nakanishi et al. (2014), Nakanishi et al. (2015) \\
\hline Fruit fly & CRISPR, TALEN, ZFN & Reviewed in Lin et al. (2014) \\
\hline Mosquito & CRISPR, TALEN, ZFN & Aryan et al. (2013), review in Reegan et al. (2017) \\
\hline Plasmodium & CRISPR, TALEN, ZFN & $\begin{array}{l}\text { Smidler at al. (2013), Straimer et al. (2012), reviewed in Singer and } \\
\text { Frischknecht (2017) }\end{array}$ \\
\hline Roundworm & CRISPR, TALEN, ZFN & reviewed in Gaj et al. (2013), Waaijers and Boxem (2014) \\
\hline Sea squirt & CRISPR, TALEN, ZFN & Kawai et al. (2012), Sasaki et al. (2014), Treen et al. (2014) \\
\hline Silkworm & CRISPR, TALEN, ZFN & Reviewed in Xu and O'Brochta (2015) \\
\hline \multicolumn{3}{|l|}{ Plants } \\
\hline Barley & CRISPR, TALEN & Lawrenson et al. (2015), Wendt et al. (2013) \\
\hline Bunchgrass & TALEN & Shang et al. (2013a) \\
\hline Cabbage & CRISPR, TALEN & Lawrenson et al. (2015), Sun et al. (2013) \\
\hline Corn & CRISPR, TALEN, ZFN & Char et al. (2015), Shukla et al. (2009), Somaratne et al. (2017) \\
\hline Chlamydomonas & CRISPR, ZFN & Shin et al. (2016), Sizova et al. (2013) \\
\hline Duncan grapefruit & CRISPR & Jia et al. (2016) \\
\hline Liverwort & CRISPR & Sugano et al. (2014) \\
\hline Petunia & CRISPR, ZFN & Marton et al. (2010), Zhang B et al. (2016a, b, c) \\
\hline Rice & CRISPR, TALEN & Li et al. (2012), reviewed in Belhaj et al. (2013) \\
\hline Sorghum & CRISPR & Jiang et al. (2013) \\
\hline Soybean & CRISPR, TALEN, ZFN & Curtin et al. (2011), Haun et al. (2014), Jacobs et al. (2015) \\
\hline Sugarcane & TALEN & Jung and Altpeter (2016) \\
\hline Sweet orange & CRISPR & Jia and Wang (2014) \\
\hline Thale cress & CRISPR, ZFN & Li et al. (2013a, b), Zhang F et al. (2010), Zhang Z et al. (2016) \\
\hline Tobacco & CRISPR, TALEN, ZFN & Li et al. (2013a, b), Townsend et al. (2009), Zhang et al. (2013) \\
\hline Wheat & CRISPR, TALEN & Shan et al. (2013b), Wang et al. (2014a) \\
\hline
\end{tabular}

Adapted from Harrison et al. 2014 and Carroll 2014. Due to the rapid pace development of targeted endonuclease-mediated mutation technologies, this table should be considered representative but not all-inclusive 
Fig. 1 Targeted endonucleases technologies such as CRISPR/ Cas9, TALEN, and ZFN induce targeted double-strand breaks that can be repaired via (1) error prone, non-homologous end joining to produce insertions and deletions, or (2) homologydirected repair with a donor template to produce specific point mutations or a variety of knock-ins (conditional ready, reporter etc.)

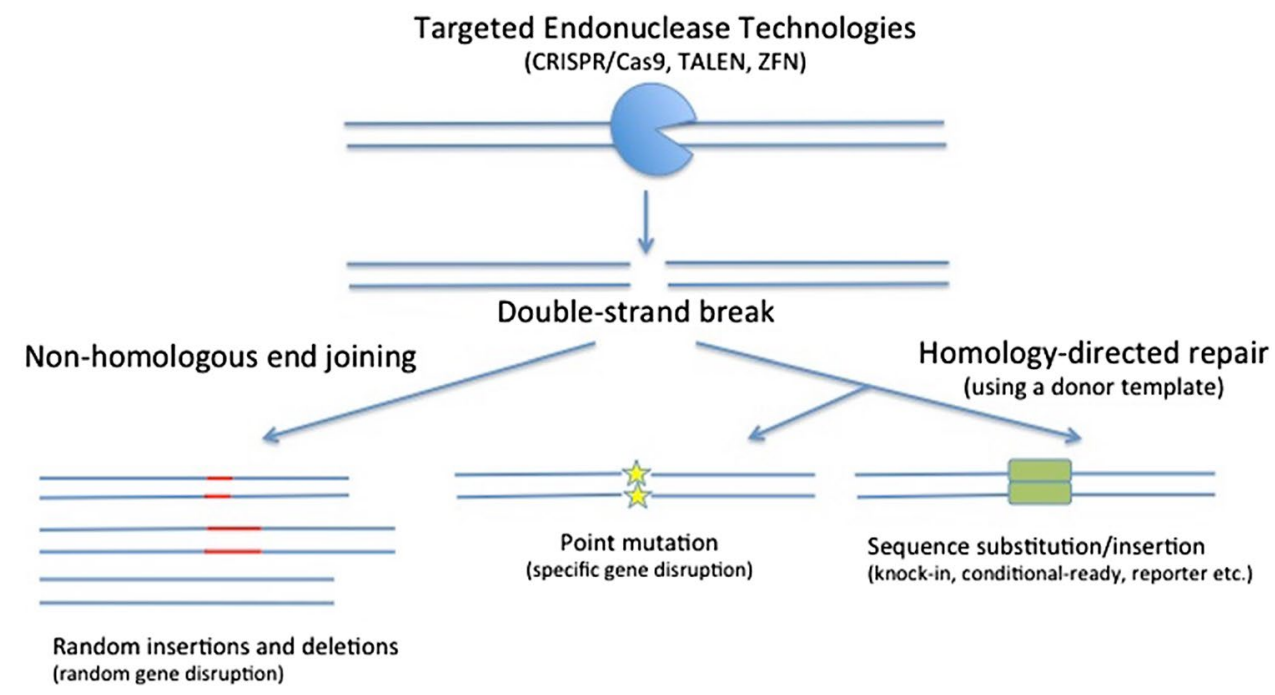

et al. 2017, reviewed in; Sander and Joung 2014; Wolfs et al. 2016; Zhang et al. 2017). In addition to biasing repair toward NHEJ, HDR or modification of histones, CRISPR/ Cas technology can be used to target more than one gene at a time (reviewed in Rocha-Martins et al. 2015).

With the prospects of creating numerous mutations per experiment, standardized nomenclature is critical to correctly identify individual heritable alleles. To be useful, symbols must not only be unambiguous but also specific, concise, and informative. While gene nomenclature has been standardized in many species, allele or mutant nomenclature guidelines vary. The major organism databases (Table 2) integrate genetic information and act as authoritative sources for gene, allele, and/or strain nomenclature. Although no standardized nomenclature exists across species to designate endonuclease-mediated mutations, the organism databases have taken two general approaches to CRISPR allele nomenclature: (1) specific endonucleasemediated mutation nomenclature, (2) standard allele and
Table 2 Summary of organismspecific nomenclature resources

\begin{tabular}{ll}
\hline Organism & Resource (website) \\
\hline $\begin{array}{l}\text { Arabidopsis thaliana } \\
\text { Caenorhabditis elegans }\end{array}$ & TAIR: The Arabidopsis Information Resource (http://www.arabidopsis.org) \\
Cattle & The Bovine Genome Database (http://www.bovinegenome.org) \\
Chicken & BirdBase (http://www.birdbase.arizona.edu/birdbase) \\
Drosophila & FlyBase (http://www.flybase.org) \\
Frog & Xenbase (http://www.xenbase.org) \\
Maize & MaizeGDB: Maize Genetics and Genomics Database (http://www.maizegdb.org) \\
Mice & MGI: Mouse Genome Informatics (http://www.informatics.jax.org) \\
Pig & Pig Genome Informatics System (http://www.pig.genomics.org.cn) \\
Rat & RGD: Rat Genome Database (http://www.rgd.mcw.edu) \\
Yeast & SDG: Saccharomyces Genome Database (http://www.yeastgenome.org) \\
Zebrafish & ZFIN: Zebrafish Information Network (http://www.zfin.org) \\
\hline
\end{tabular}


mutation nomenclature, or (3) adopting HGNC nomenclature guidelines.

\section{Unique endonuclease-mediated mutation allele nomenclature (mouse, rat, and Xenopus)}

The International Committee on Standardized Genetic Nomenclature for Mice and the Rat Genome Nomenclature Committee has established guidelines for the nomenclature of genes, genetic markers, alleles, and mutations in mouse (http://www.informatics.jax.org; Blake et al. 2017) and rat (http://rgd.mcw.edu; Shimoyama et al. 2015). Allele symbols are composed of the modified gene with the allele information in superscript (http://www.informatics.jax.org/ mgihome/nomen/gene.shtml\#endim). The allele information includes method of generation, serial number for the number of alleles generated by the laboratory in the gene, and laboratory code registered with ILAR (International Laboratory Animal Research; http://dels.nas.edu/global/ ilar/lab-codes). For example, Apoc2 ${ }^{\text {emlArem }}$ represents the first endonuclease-mediated mutation generated in the apolipoprotein C-II gene by the laboratory of Dr. Alan Remaley (Sakurai et al. 2016). Likewise, Mecp2 $2^{\text {emISage }}$ represents the first endonuclease-mediated mutation generated in the methyl $\mathrm{CpG}$ binding protein 2 gene by Sigma Advanced Genetic (Wu et al. 2016). The endonucleasemediated mutation (em) includes mutations generated by TALENs, ZFNs, CRISPR/Cas, and any potential future technologies that utilize targeted endonucleases to nick the DNA and modify the genome.

Beyond standard em allele nomenclature, MGI utilizes chromosomal aberration nomenclature when CRISPRguided target sequences flanking more than one gene (http://www.informatics.jax.org/mgihome/nomen/anomalies.shtml). For example, Del(5Kit-Nmu)2Staka represents an endonuclease-mediated mutation that results in a deletion on chromosome five spanning from KIT proto-oncogene receptor tyrosine kinase to neuromedin $\mathrm{U}$ that is the second deletion generated in the laboratory of Dr. Satoru Takahashi (Mizuno et al. 2015). The ability to associate alleles to more than one gene via a mutation involves relationship provides access to this allele via all the markers affected in the deletion (Eppig et al. 2015).

To facilitate searching for em alleles whether the allele targets one or more genes, MGI tags the alleles with generation-type 'endonuclease-mediated' and the exact endonuclease technology is further specified in the molecular details and origin in MGI and RGD, respectively, on allele detail pages. For example, Smg $9^{\text {emlJ }}$ (http://www.informatics.jax.org/allele/key/853643; Shaheen et al. 2016) is annotated with the allele generation attribute 'endonuclease-mediated mutation.' The mutation details describe the allele in detail. The combination of endonuclease-mediated mutation-specific allele symbols and metadata tags identifies CRISPR/Cas-generated alleles and facilitates phenotypic and disease-association analysis in MGI and RGD.

Xenbase (http://www.xenbase.org; James-Zorn et al. 2015 and Karpinka et al. 2015) is the research community resource that integrates data for Xenopus tropicalis and Xenopus laevis. The frog community utilizes nomenclature based on the nomenclature guidelines established by the International Committee on Standardized Genetic Nomenclature for Mice. Endonuclease-mediated mutations are represented by nomenclature that includes the three letter species code, period, gene symbol, method of generation, a serial number for mutations in the particular locus generated by a particular laboratory and the ILAR registered laboratory code. For example, Xtr.gsc ${ }^{\text {emICho }}$ represents the first endonuclease-mediated mutation in the goosecoid homeobox gene from the laboratory of Dr. Cho in Xenopus tropicalis (Blitz et al. 2016).

\section{Use of existing allele nomenclature for endonuclease-mediated mutations} (Arabidopsis, C. elegans, Drosophila, Maize, Yeast, and Zebrafish)

A number of model organisms and research organism databases utilize existing organism-specific standardized nomenclature to describe CRISPR/Cas-generated alleles and mutants.

The Arabidopsis Information Resource (TAIR; https:// www.arabidopsis.org/; Berardini et al. 2015) is the authoritative source for Arabidopsis thaliana gene and mutant nomenclature. Alleles are designated by the gene symbol, hyphen, and serial number for mutations in that gene (The Arabidopsis Information Resource 2017). For example, idm3-4 represents the fourth mutation in the increased DNA methylation 3 gene (Lang et al. 2015). The mutagen field on the allele detail page reflects generation using CRISPR technology.

WormBase (http://www.wormbase.org; Harris et al. 2010), a community research resource for Caenorhabditis elegans and related nematodes, alleles are described by a one- or two-letter laboratory code which refers to the laboratory of isolation, registered at the Caenorhabditis Genetic Center (CGC; https://cbs.umn.edu/cgc/home) and serial number corresponding to the number of mutations generated by the specific laboratory. For example, ect2(xs110) is the one hundred tenth variant generated by the laboratory of Dr. M Glotzer in the ECT2 (mammalian Rho GEF) homolog gene (Zhang and Glotzer 2015). While optional suffixes exist for generation methods (e.g., transposonexcision, te) and consequence (e.g., temperature-sensitive, 
ts), there is no current suffix for endonuclease-mediated mutation. A method of generation tag specifies generation by CRISPR technology and can be viewed using the Tree Display tool on the variation detail page. The WormBase Query Language can be used to search for "CRISPR/Cas9" as a production method. Additionally, WormMine release WS259 will allow users to search for engineered alleles (personal communication from WormBase).

Flybase (http://flybase.org/; Gramates et al. 2017) is a database of Drosophila genes and genomes. Allele nomenclature consists of the species symbol, backslash, gene, and allele name provided by the generating laboratory in superscript (Flybase 2017). For example, Dme $e^{H D R-C R I S P R}$ is the HDR-CRISPR mutation in the Drosophila melanogaster ebony gene. There is no nomenclature requirement to include CRISPR as a part of the allele symbol. The mutagen field on the allele detail page labels this allele as being generated by CRISPR/Cas technology.

MaizeGDB (http://www.maizegdb.org; Andorf et al. 2016) is a maize genetics and genomics database. Allele nomenclature is composed of the gene symbol plus a letter or numbers corresponding to the mutation. The generating laboratory assigns the numbers and or line name. The number corresponds to the serial number of all mutations in the given gene. For example, ms10-CRISPRl represents the CRISPR1 mutation in the male sterile 10 gene (Somaratne et al. 2017). There is no requirement to include CRISPR in the allele symbol as a part of the laboratory line number or name. The mutagen field on the variation record captures the method of generation by CRISPR/Cas-technology.

Saccharomyces Genome Database (http://www.yeastgenome.org/; Cherry et al. 2012) is a research database dedicated to the budding yeast Saccharomyces cerevisiae. They are the authoritative source for yeast gene and mutant nomenclature (Cherry 1995). Mutant yeast nomenclature utilizes characters that represent the nature of the genomic modification in addition to gene symbols. For example, ade6::URA4 would represent a disruption in the phosphoribosylformylglycinamidine synthase gene with the insertion of a functional dihydroorotase gene. There is no current symbol to represent endonuclease-mediated mutations such as those generated by CRISPR/Cas technology (personal communication SGD Project 2017).

In the Zebrafish Information Network (https://zfin.org/; Howe et al. 2013), allele and mutation symbols are based on the resulting genetic disruption produced by a given laboratory using laboratory codes registered with ZFIN. For example, kif5ba $a^{a e 11}$ represents the eleventh mutation in the kinesin family member $5 \mathrm{~B}$ gene generated by the laboratory of Dr. Marlow (Campbell et al. 2015). While the nomenclature schema does not include a character to represent CRISPR-generated alleles, information about the method of generation is stated as an experiment-specific mutagen in the protocol field of the allele detail page and mutagen field on the gene detail page, respectively.

\section{Standard HGNC allele nomenclature (cattle, chicken, and pig)}

While databases exist for genomic research in several agricultural organisms (see Table 2), their focus is on genome annotation and spontaneous or engineered alleles are not generally annotated for these organisms. In the absence of standard allele nomenclature, several agricultural organisms have adopted guidelines in keeping with HUGO Gene Nomenclature Committee (HGNC) guidelines (http://www. genenames.org/, Yates et al. 2017). The general recommendation by HGNC is to represent an allele using the gene symbol, an asterisk and the allele symbol on the same line (e.g., PGM1*1; Wain et al. 2002). This includes livestock species such as cattle, chicken, and pig (Burt et al. 2009; Hu et al. 2011, 2014).

\section{Summary}

The continued development of new technologies for generating germline modifications in different species poses a nomenclature challenge for the scientific community. While nomenclature conventions continue to evolve when the need arises to represent new information, the stability and concise nature of unambiguous and specific symbols and names is the purpose of standardized nomenclature. Although the various organism-specific communities have opted for different approaches, they nevertheless provide researchers with the ability to identify endonuclease-mediated mutations by symbol and/or metadata tag.

In addition to promoting the reproducibility of data by unambiguously identifying alleles, standard nomenclature facilitates the integration and analysis of phenotypic data across species. Tools are emerging to allow for high-level comparison of annotated data across species at the level of the gene or phenotype. InterMine offers a platform for cross species comparison (http://intermine.org/; Lyne et al. 2015). Mines have been established for several model organisms, including fly, frog, human, mouse, rat, worm, yeast and zebrafish, and for specialized research area such as mitochondrial proteomics and modENCODE data (see http://intermine.org/). The Alliance of Genome Resources (AGR; http://home.alliancegenome.org), an intersection between six major model organism databases (MGI, RGD, SGD, ZFIN, FlyBase and WormBase), aims to allow for cross species comparison for analysis of genetic, phenotypic, and disease-related annotations. The Monarch Initiative (monarchinitiative.org; Mungall et al. 2017) integrates 
genotype to phenotype data across multiple species to support biomedical research. MouseNet2 (http://www.inetbio. org/mousenet/; Kim et al. 2016) integrates gene network data, particularly from microarray experiments, for the discovery of novel disease genes and disease pathways.

The rapidly evolving technologies utilizing targeted endonuclease-mediated mutation to create new alleles will continue to generate numerous somatic and germline mutations. These tools will expand our understanding of basic biology and disease models in addition to offering a method to repair or treat existing mutations faster and with greater ease than previous mutagenesis technologies. As scientists continue to refine their ability to induce and repair genetic mutations, the need for unambiguous identification of their tools and genetic products becomes all the more important.

Acknowledgements We would like to thank the following people for their assistance in determining the nomenclature guidelines for different species: Tanya Berardini and Benson Lindsey (TAIR), Stacia R Engel (SGD), Christina James-Zorn (Xenbase), Fiona McCarthy and James M Reecy (cattle, chicken and pig nomenclature), Gillian Millburn (FlyBase), Marty Sachs (MaizeGDB), Amy G Singer (ZFIN), Mary Ann Tuli (WormBase). Supported by National Institutes of Health Grant HG000330.

Open Access This article is distributed under the terms of the Creative Commons Attribution 4.0 International License (http:// creativecommons.org/licenses/by/4.0/), which permits unrestricted use, distribution, and reproduction in any medium, provided you give appropriate credit to the original author(s) and the source, provide a link to the Creative Commons license, and indicate if changes were made.

\section{References}

Andorf CM, Cannon EK, Portwood JL, Gardiner JM, Harper LC, Schaeffer ML, Braun BL, Campbell DA, Vinnakota AG, Sribalusu VV, Huerta M, Cho KT, Wimalanathan K, Richter JD, Mauch ED, Rao BS, Birkett SM, Sen TZ, Lawrence-Dill CJ (2016) MaizeGDB update: new tools, data and interface for the maize model organism database. Nucleic Acids Res 44(D1):D1195-D1201. doi:10.1093/nar/gkv1007

Ansai S, Kinoshita M (2014) Targeted mutagenesis using CRISPR/ Cas system in medaka. Biol Open 3(5):362-371. doi:10.1242/ bio. 20148177

Aryan A, Anderson MA, Myles KM, Adelman ZN (2013) TALENbased gene disruption in the dengue vector Aedes aegypti. PLoS One 8(3):e60082. doi:10.1371/journal.pone.0060082

Auer TO, Duroure K, De Cian A, Concordet JP, Del Bene F (2014) Highly efficient CRISPR/Cas9-mediated knock-in in zebrafish by homology-independent DNA repair. Genome Res 24(1):142153. doi:10.1101/gr.161638.113

Awata H, Watanabe T, Hamanaka Y, Mito T, Noji S, Mizunami M (2015) Knockout crickets for the study of learning and memory: dopamine receptor Dop1 mediates aversive but not appetitive reinforcement in crickets. Sci Rep 5:15885. doi:10.1038/ srep15885

Belhaj K, Chaparro-Garcia A, Kamoun S, Nekrasov V (2013) Plant genome editing made easy: targeted mutagenesis in model and crop plants using the CRISPR/Cas system. Plant Methods 9(1):39. doi:10.1186/1746-4811-9-39

Berardini TZ, Reiser L, Li D, Mezheritsky Y, Muller R, Strait E, Huala E (2015) The Arabidopsis information resource: making and mining the "gold standard" annotated reference plant genome. Genesis 53(8):474-485. doi:10.1002/dvg.22877

Blake JA, Eppig JT, Kadin JA, Richardson JE, Smith CL, Bult CJ, the Mouse Genome Database Group (2017) Mouse Genome Database (MGD)-2017: community knowledge resource for the laboratory mouse. Nucl Acids Res 45(D1):D723-D729. doi:10.1093/nar/gkw1040

Blitz IL, Fish MB, Cho KW (2016) Leapfrogging: primordial germ cell transplantation permits recovery of CRISPR/ Cas9-induced mutations in essential genes. Development 143(15):2868-2875. doi:10.1242/dev.138057

Burt DW, Carrë W, Fell M, Law AS, Antin PB, Maglott DR, Weber JA, Schmidt CJ, Burgess SC, McCarthy FM (2009) The chicken gene nomenclature committee report. BMC Genom 10(Suppl 2):S5. doi:10.1186/1471-2164-10-S2-S5

Campbell PD, Heim AE, Smith MZ, Marlow FL (2015) Kinesin-1 interacts with bucky ball to form germ cells and is required to pattern the zebrafish body axis. Development 142(17):29963008. doi:10.1242/dev.124586

Carroll D (2014) Genome engineering with targetable nucleases. Annu Rev Biochem 83:409-439. doi:10.1146/ annurev-biochem-060713-035418

Char SN, Unger-Wallace E, Frame B, Briggs SA, Main M, Spalding $\mathrm{MH}$, Vollbrecht E, Wang K, Yang B (2015) Heritable sitespecific mutagenesis using TALENs in maize. Plant Biotechnol J 13(7):1002-1010. doi:10.1111/pbi.12344

Chen L, Tang L, Xiang H, Jin L, Li Q, Dong Y, Wang W, Zhang G (2014) Advances in genome editing technology and its promising application in evolutionary and ecological studies. Gigascience 3:24. doi:10.1186/2047-217X-3-24

Cherry JM (1995) Genetic nomenclature guide: Saccharomyces cerevisiae. Trends Genet Mar:11-12

Cherry JM, Hong EL, Amundsen C, Balakrishnan R, Binkley G, Chan ET, Christie KR, Costanzo MC, Dwight SS, Engel SR, Fisk DG, Hirschman JE, Hitz BC, Karra K, Krieger CJ, Miyasato SR, Nash RS, Park J, Skrzypek MS, Simison M, Weng S, Wong ED (2012) Saccharomyces genome database: the genomics resource of budding yeast. Nucleic Acids Res 40(Database issue):D700-D705. doi:10.1093/nar/gkr1029

Curtin SJ, Zhang F, Sander JD, Haun WJ, Starker C, Baltes NJ, Reyon D, Dahlborg EJ, Goodwin MJ, Coffman AP, Dobbs D, Joung JK, Voytas DF, Stupar RM (2011) Targeted mutagenesis of duplicated genes in soybean with zinc-finger nucleases. Plant Physiol 156(2):466-473. doi:10.1104/pp.111.172981

Dong Z, Ge J, Li K, Xu Z, Liang D, Li J, Li J, Jia W, Li Y, Dong X, Cao S, Wang X, Pan J, Zhao Q (2011) Heritable targeted inactivation of myostatin gene in yellow catfish (Pelteobagrus fulvidraco) using engineered zinc finger nucleases. PLoS ONE 6(12):e28897. doi:10.1371/journal.pone.0028897

Dong Z, Ge J, Xu Z, Dong X, Cao S, Pan J, Zhao Q (2014) Generation of myostatin B knockout yellow catfish (Tachysurus fulvidraco) using transcription activator-like effector nucleases. Zebrafish 11(3):265-274. doi:10.1089/zeb.2014.0974

Eppig JT, Blake JA, Bult CJ, Kadin JA, Richardson JE, Mouse Genome Database Group (2015) The Mouse genome database (MGD): facilitating mouse as a model for human biology and disease. Nucleic Acids Res 43(Database issue):D726-36. doi:10.1093/nar/gku967

Fei JF, Schuez M, Tazaki A, Taniguchi Y, Roensch K, Tanaka EM (2014) CRISPR-mediated genomic deletion of Sox 2 in the axolotl shows a requirement in spinal cord neural stem 
cell amplification during tail regeneration. Stem Cell Rep 3(3):444-459. doi:10.1016/j.stemcr.2014.06.018

Flisikowska T, Thorey IS, Offner S, Ros F, Lifke V, Zeitler B, Rottmann O, Vincent A, Zhang L, Jenkins S, Niersbach H, Kind AJ, Gregory PD, Schnieke AE, Platzer J (2011) Efficient immunoglobulin gene disruption and targeted replacement in rabbit using zinc finger nucleases. PLoS ONE 6(6):e21045. doi:10.1371/journal.pone.0021045

Flowers GP, Timberlake AT, McLean KC, Monaghan JR, Crews CM (2014) Highly efficient targeted mutagenesis in axolotl using Cas9 RNA-guided nuclease. Development 141(10):2165-2171. doi:10.1242/dev.105072

Flybase (2017) http://flybase.org/wiki/FlyBase:Nomenclature. Accessed 14 Feb 2017

Gaj T, Gersbach CA, Barbas CF 3rd (2013) ZFN, TALEN, and CRISPR/Cas-based methods for genome engineering. Trends Biotechnol 31(7):397-405. doi:10.1016/j.tibtech.2013.04.004

Gramates LS, Marygold SJ, dos Santos G, Urbano J-M, Antonazzo G, Matthews BB, Rey AJ, Tabone CJ, Crosby MA, Emmert DB, Falls K, Goodman JL, Hu Y, Ponting L, Schroeder AJ, Strelets VB, Thurmond J, Zhou P, the FlyBase Consortium (2017) FlyBase at 25: looking to the future. Nucleic Acids Res 45(D1):D663-D671. doi:10.1093/nar/gkw1016

Guan G, Zhang X, Naruse K, Nagahama Y, Hong Y (2014) Gene replacement by zinc finger nucleases in medaka embryos. Mar Biotechnol 16(6):739-747. doi:10.1007/s10126-014-9587-7

Guha TK, Wai A, Hausner G (2017) Programmable genome editing tools and their regulation for efficient genome engineering. Comput Struct Biotechnol J 15:146-160. doi:10.1016/j. csbj.2016.12.006

Harris TW, Antoshechkin I, Bieri T, Blasiar D, Chan J, Chen WJ, De La Cruz N, Davis P, Duesbury M, Fang R, Fernandes J, Han M, Kishore R, Lee R, Müller HM, Nakamura C, Ozersky P, Petcherski A, Rangarajan A, Rogers A, Schindelman G, Schwarz EM, Tuli MA, Van Auken K, Wang D, Wang X, Williams G, Yook K, Durbin R, Stein LD, Spieth J, Sternberg PW (2010) WormBase: a comprehensive resource for nematode research. Nucleic Acids Res 38(Database issue):D463-D467. doi:10.1093/nar/ gkp952

Harrison MM, Jenkins BV, O'Connor-Giles KM, Wildonger J (2014) A CRISPR view of development. Genes Dev 28(17):18591872. doi:10.1101/gad.248252.114

Haun W, Coffman A, Clasen BM, Demorest ZL, Lowy A, Ray E, Retterath A, Stoddard T, Juillerat A, Cedrone F, Mathis L, Voytas DF, Zhang F (2014) Improved soybean oil quality by targeted mutagenesis of the fatty acid desaturase 2 gene family. Plant Biotechnol J 12(7):934-940. doi:10.1111/pbi.12201

Hayashi T, Sakamoto K, Sakuma T, Yokotani N, Inoue T, Kawaguchi E, Agata K, Yamamoto T, Takeuchi T (2014) Transcription activator-like effector nucleases efficiently disrupt the target gene in Iberian ribbed newts (Pleurodeles waltl), an experimental model animal for regeneration. Dev Growth Differ 56:115121. doi:10.1111/dgd. 12103

Honda A, Hirose M, Sankai T, Yasmin L, Yuzawa K, Honsho K, Izu H, Iguchi A, Ikawa M, Ogura A (2015) Single-step generation of rabbits carrying a targeted allele of the tyrosinase gene using CRISPR/Cas9. Exp Anim 64(1):31-37. doi:10.1538/ expanim.14-0034

Howe DG, Bradford YM, Conlin T, Eagle AE, Fashena D, Frazer K, Knight J, Mani P, Martin R, Moxon SA, Paddock H, Pich C, Ramachandran S, Ruef BJ, Ruzicka L, Schaper K, Shao X, Singer A, Sprunger B, Van Slyke CE, Westerfield M (2013) ZFIN, the Zebrafish Model Organism Database: increased support for mutants and transgenics. Nucleic Acids Res 41(Database issue):D854-D860. doi:10.1093/nar/gks938
Hu Z, Park CA, Reecy JM (2011) Standard genetic nomenglature[sic] of the pig, with glossaries. Animal Science Publications. http:// lib.dr.iastate.edu/ans_pubs/172

Hu Z, Reecy JM, McCarthy FM, Park CA (2014) Standard genetic nomenclature. Animal Science Publications. http://lib.dr.iastate. edu/ans_pubs/171

International Committee on Standardized Genetic Nomenclature for Mice (2015) Guidelines for nomenclature of genes, genetic markers, alleles, and mutations in mouse and rat. http://www. informatics.jax.org/mgihome/nomen/gene.shtml. Accessed 17 Mar 2017

International Committee on Standardized Genetic Nomenclature for Mice (2016) Rules for nomenclature of mouse chromosome aberrations http://www.informatics.jax.org/mgihome/nomen/ anomalies.shtml. Accessed 17 Mar 2017

Jacobs TB, LaFayette PR, Schmitz RJ, Parrott WA (2015) Targeted genome modifications in soybean with CRISPR/Cas9. BMC Biotechnol 15:16. doi:10.1186/s12896-015-0131-2

James-Zorn C, Ponferrada VG, Burns KA, Fortriede JD, Lotay VS, Liu Y, Brad Karpinka J, Karimi K, Zorn AM, Vize PD (2015) Xenbase: core features, data acquisition, and data processing. Genesis 53(8):486-497. doi:10.1002/dvg.22873

Jia H, Wang N (2014) Targeted genome editing of sweet orange using Cas9/sgRNA. PLoS ONE 9(4):e93806. doi:10.1371/journal. pone.0093806

Jia H, Orbovic V, Jones JB, Wang N (2016) Modification of the PthA4 effector binding elements in Type I CsLOB1 promoter using Cas9/sgRNA to produce transgenic Duncan grapefruit alleviating Xec $\Delta$ pthA4:dCsLOB1.3 infection. Plant Biotechnol J 14(5):1291-1301. doi:10.1111/pbi.12495

Jiang W, Zhou H, Bi H, Fromm M, Yang B, Weeks DP (2013) Demonstration of CRISPR/Cas9/sgRNA-mediated targeted gene modification in Arabidopsis, tobacco, sorghum and rice. Nucleic Acids Res 41(20):e188. doi:10.1093/nar/gkt780

Jung JH, Altpeter F (2016) TALEN mediated targeted mutagenesis of the caffeic acid $O$-methyltransferase in highly polyploid sugarcane improves cell wall composition for production of bioethanol. Plant Mol Biol 92(1-2):131-142. doi:10.1007/ s11103-016-0499-y

Karpinka JB, Fortriede JD, Burns KA, James-Zorn C, Ponferrada VG, Lee J, Karimi K, Zorn AM, Vize PD (2015) Xenbase, the Xenopus model organism database; new virtualized system, data types and genomes. Nucleic Acids Res 43(Database issue):D756-D763. doi:10.1093/nar/gku956

Kawai N, Ochiai H, Sakuma T, Yamada L, Sawada H, Yamamoto T, Sasakura Y (2012) Efficient targeted mutagenesis of the chordate Ciona intestinalis genome with zincfinger nucleases. Dev Growth Differ 54(5):535-545. doi:10.1111/j.1440-169X.2012.01355.x

Kim E, Hwang S, Kim H, Shim H, Kang B, Yang S, Shim JH, Shin SY, Marcotte EM, Lee I (2016) MouseNet v2: a database of gene networks for studying the laboratory mouse and eight other model vertebrates. Nucleic Acids Res 44(D1):D848D854. doi:10.1093/nar/gkv1155

Lang Z, Lei M, Wang X, Tang K, Miki D, Zhang H, Mangrauthia SK, Liu W, Nie W, Ma G, Yan J, Duan CG, Hsu CC, Wang C, Tao WA, Gong Z, Zhu JK (2015) The methyl-CpG-binding protein MBD7 facilitates active DNA demethylation to limit DNA hyper-methylation and transcriptional gene silencing. Mol Cell 57(6):971-983. doi:10.1016/j.molcel.2015.01.009

Lawrenson T, Shorinola O, Stacey N, Li C, Østergaard L, Patron N, Uauy C, Harwood W (2015) Induction of targeted, heritable mutations in barley and Brassica oleracea using RNAguided Cas9 nuclease. Genome Biol 16:258. doi:10.1186/ s13059-015-0826-7 
Li T, Liu B, Spalding MH, Weeks DP, Yang B (2012) High-efficiency TALEN-based gene editing produces disease-resistant rice. Nat Biotechnol 30(5):390-392. doi:10.1038/nbt.2199

Li JF, Norville JE, Aach J, McCormack M, Zhang D, Bush J, Church GM, Sheen J (2013a) Multiplex and homologous recombination-mediated genome editing in Arabidopsis and Nicotiana benthamiana using guide RNA and Cas9. Nat Biotechnol 31(8):688-691. doi:10.1038/nbt.2654

Li MH, Yang HH, Li MR, Sun YL, Jiang XL, Xie QP, Wang TR, Shi HJ, Sun LN, Zhou LY, Wang DS (2013b) Antagonistic roles of Dmrt1 and Fox12 in sex differentiation via estrogen production in tilapia as demonstrated by TALENs. Endocrinology 154(12):4814-4825. doi:10.1210/en.2013-1451

Li M, Yang H, Zhao J, Fang L, Shi H, Li M, Sun Y, Zhang X, Jiang D, Zhou L, Wang D (2014) Efficient and heritable gene targeting in tilapia by CRISPR/Cas9. Genetics 197(2):591-599. doi:10.1534/genetics.114.163667

Li M, Feng R, Ma H, Dong R, Liu Z, Jiang W, Tao W, Wang D (2016) Retinoic acid triggers meiosis initiation via stra8dependent pathway in Southern catfish, Silurus meridionalis. Gen Comp Endocrinol 232:191-198. doi:10.1016/j. ygcen.2016.01.003

Lin SC, Chang YY, Chan CC (2014) Strategies for gene disruption in Drosophila. Cell Biosci 4(1):63. doi:10.1186/2045-3701-4-63

Lyne R, Sullivan J, Butano D, Contrino S, Heimbach J, Hu F, Kalderimis A, Lyne M, Smith RN, Štěpán R, Balakrishnan R, Binkley G, Harris T, Karra K, Moxon SA, Motenko H, Neuhauser S, Ruzicka L, Cherry M, Richardson J, Stein L, Westerfield M, Worthey E, Micklem G (2015) Cross-organism analysis using InterMine. Genesis 53(8):547-560. doi:10.1002/dvg.22869

Markert MJ, Zhang Y, Enuameh MS, Reppert SM, Wolfe SA, Merlin $\mathrm{C}$ (2016) Genomic access to monarch migration using TALEN and CRISPR/Cas9-mediated targeted mutagenesis. G3 6(4):905-915. doi:10.1534/g3.116.027029

Marton I, Zuker A, Shklarman E, Zeevi V, Tovkach A, Roffe S, Ovadis M, Tzfira T, Vainstein A (2010) Nontransgenic genome modification in plant cells. Plant Physiol 154(3):1079-1087. doi:10.1104/pp.110.164806

Mashimo T (2014) Gene targeting technologies in rats: zinc finger nucleases, transcription activator-like effector nucleases, and clustered regularly interspaced short palindromic repeats. Dev Growth Differ 56(1):46-52. doi:10.1111/dgd.12110

Menchaca A, Anegon I, Whitelaw CB, Baldassarre H, Crispo M (2016) New insights and current tools for genetically engineered (GE) sheep and goats. Theriogenology 86(1):160-169. doi:10.1016/j.theriogenology.2016.04.028

Merlin C, Beaver LE, Taylor OR, Wolfe SA, Reppert SM (2013) Efficient targeted mutagenesis in the monarch butterfly using zincfinger nucleases. Genome Res 23(1):159-168. doi:10.1101/ gr.145599.112

Mizuno S, Takami K, Daitoku Y, Tanimoto Y, Dinh TT, MizunoIijima S, Hasegawa Y, Takahashi S, Sugiyama F, Yagami K (2015) Peri-implantation lethality in mice carrying megabasescale deletion on 5 qc3.3 is caused by Exoc1 null mutation. Sci Rep 5:13632. doi: $10.1038 /$ srep13632

Mungall CJ, McMurry JA, Köhler S, Balhoff JP, Borromeo C, Brush M, Carbon S, Conlin T, Dunn N, Engelstad M, Foster E, Gourdine JP, Jacobsen JO, Keith D, Laraway B, Lewis SE, NguyenXuan J, Shefchek K, Vasilevsky N, Yuan Z, Washington N, Hochheiser H, Groza T, Smedley D, Robinson PN, Haendel MA (2017) The monarch Initiative: an integrative data and analytic platform connecting phenotypes to genotypes across species. Nucleic Acids Res 45(D1):D712-D722. doi:10.1093/nar/ gkw1128

Naitou A, Kato Y, Nakanishi T, Matsuura T, Watanabe H (2015) Heterodimeric TALENs induce targeted heritable mutations in the crustacean Daphnia magna. Biol Open 4(3):364-369. doi:10.1242/bio.20149738

Nakanishi T, Kato Y, Matsuura T, Watanabe H (2014) CRISPR/Casmediated targeted mutagenesis in Daphnia magna. PLoS ONE 9(5):e98363. doi:10.1371/journal.pone.0098363

Nakanishi T, Kato Y, Matsuura T, Watanabe H (2015) TALEN-mediated homologous recombination in Daphnia magna. Sci Rep 5:18312. doi:10.1038/srep18312

Niu Y, Shen B, Cui Y, Chen Y, Wang J, Wang L, Kang Y, Zhao X, $\mathrm{Si} \mathrm{W}, \mathrm{Li} \mathrm{W}$ et al (2014) Generation of gene-modified cynomolgus monkey via Cas9/RNA-mediated gene targeting in one-cell embryos. Cell 156(4):836-843. doi:10.1016/j.cell.2014.01.027

Reegan AD, Ceasar SA, Paulraj MG, Ignacimuthu S, Al-Dhabi NA (2017) Current status of genome editing in vector mosquitoes: a review. Biosci Trends 10(6):424-432. doi:10.5582/ bst.2016.01180

Rocha-Martins M, Cavalheiro GR, Matos-Rodrigues GE, Martins RA (2015) From gene targeting to genome editing: transgenic animals applications and beyond. An Acad Bras Cienc 87(2 Suppl):1323-1348. doi:10.1590/0001-3765201520140710

Sakurai T, Sakurai A, Vaisman BL, Amar MJ, Liu C, Gordon SM, Drake SK, Pryor M, Sampson ML, Yang L, Freeman LA, Remaley AT (2016) Creation of Apolipoprotein C-II (ApoCII) mutant mice and correction of their Hypertriglyceridemia with an ApoC-II mimetic peptide. J Pharmacol Exp Ther 356(2):341-353. doi:10.1124/jpet.115.229740

Sander JD, Joung JK (2014) CRISPR-Cas systems for editing, regulating and targeting genomes. Nat Biotechnol 32(4):347-355. doi: $10.1038 /$ nbt. 2842

Sasaki H, Yoshida K, Hozumi A, Sasakura Y (2014) CRISPR/Cas9mediated gene knockout in the ascidian Ciona intestinalis. Dev Growth Differ 56(7):499-510. doi:10.1111/dgd.12149

Sato M, Miyoshi K, Nagao Y, Nishi Y, Ohtsuka M, Nakamura S, Sakurai T, Watanabe S (2014) The combinational use of CRISPR/Cas9-based gene editing and targeted toxin technology enables efficient biallelic knockout of the a-1,3- galactosyltransferase gene in porcine embryonic fibroblasts. Xenotransplantation 21:291-300. doi:10.1111/xen.12089

Seruggia D, Montoliu L (2014) The new CRISPR-Cas system: RNAguided genome engineering to efficiently produce any desired genetic alteration in animals. Transgenic Res 23(5):707-716. doi:10.1007/s11248-014-9823-y

SGD Project (2017) Saccharomyces cerevisiae. http://www.yeastgenome.org/sgdpub/Saccharomyces_cerevisiae.pdf. Accessed $13 \mathrm{Feb} 2017$

Shaheen R, Anazi S, Ben-Omran T, Seidahmed MZ, Caddle LB, Palmer K, Ali R, Alshidi T, Hagos S, Goodwin L, Hashem M, Wakil SM, Abouelhoda M, Colak D, Murray SA, Alkuraya FS (2016) Mutations in SMG9, encoding an essential component of nonsense-mediated decay machinery, cause a multiple Congenital anomaly syndrome in humans and mice. Am J Hum Genet 98(4):643-652. doi:10.1016/j.ajhg.2016.02.010

Shan Q, Wang Y, Chen K, Liang Z, Li J, Zhang Y, Zhang K, Liu J, Voytas DF, Zheng X, Zhang Y, Gao C (2013a) Rapid and efficient gene modification in rice and Brachypodium using TALENs. Mol Plant 6(4):1365-1368. doi:10.1093/mp/sss 162

Shan Q, Wang Y, Li J, Zhang Y, Chen K, Liang Z, Zhang K, Liu J, Xi JJ, Qiu JL, Gao C (2013b) Targeted genome modification of crop plants using a CRISPR-Cas system. Nat Biotechnol 31(8):686-688. doi:10.1038/nbt.2650

Shi Z, Tian D, Xin H, Lian J, Guo X, Chen Y (2017) Targeted integration of genes in Xenopus tropicalis. Genesis 55(1-2). doi:10.1002/dvg.23006

Shimoyama M, De Pons J, Hayman GT, Laulederkind SJ, Liu W, Nigam R, Petri V, Smith JR, Tutaj M, Wang SJ, Worthey E, Dwinell M, Jacob H (2015) The rat genome database 2015: 
genomic, phenotypic and environmental variations and disease. Nucleic Acids Res 43(Database issue):D743-D750. doi:10.1093/nar/gku1026

Shin SE, Lim JM, Koh HG, Kim EK, Kang NK, Jeon S, Kwon S, Shin WS, Lee B, Hwangbo K, Kim J, Ye SH, Yun JY, Seo H, Oh HM, Kim KJ, Kim JS, Jeong WJ, Chang YK, Jeong BR (2016) CRISPR/Cas9-induced knockout and knock-in mutations in Chlamydomonas reinhardtii. Sci Rep 6:27810. doi:10.1038/srep27810

Shukla VK, Doyon Y, Miller JC, DeKelver RC, Moehle EA, Worden SE, Mitchell JC, Arnold NL, Gopalan S et al (2009) Precise genome modification in the crop species Zea mays using zinc-finger nucleases. Nature 459(7245):437-441. doi:10.1038/nature07992

Singer M, Frischknecht F (2017) Time for genome editing: nextgeneration attenuated Malaria Parasites. Trends Parasitol 33(3):202-213. doi:10.1016/j.pt.2016.09.012

Sizova I, Greiner A, Awasthi M, Kateriya S, Hegemann P (2013) Nuclear gene targeting in Chlamydomonas using engineered zinc-finger nucleases. Plant J 73(5):873-882. doi:10.1111/ tpj. 12066

Smidler AL, Terenzi O, Soichot J, Levashina EA, Marois E (2013) Targeted mutagenesis in the malaria mosquito using TALE nucleases. PLoS ONE 8(8):e74511. doi:10.1371/journal. pone.0074511

Somaratne Y, Tian Y, Zhang H, Wang M, Huo Y, Cao F, Zhao L, Chen H (2017) Abnormal Pollen Vacuolation1 (APV1) is required for male fertility by contributing to anther cuticle and pollen exine formation in maize. Plant J 90(1):96-110. doi:10.1111/tpj.13476

Straimer J, Lee MC, Lee AH, Zeitler B, Williams AE, Pearl JR, Zhang L, Rebar EJ, Gregory PD, Llinás M, Urnov FD, Fidock DA (2012) Site-specific genome editing in Plasmodium falciparum using engineered zinc-finger nucleases. Nat Methods 9(10):993-998. doi:10.1038/nmeth.2143

Sugano SS, Shirakawa M, Takagi J, Matsuda Y, Shimada T, HaraNishimura I, Kohchi T (2014) CRISPR/Cas9-mediated targeted mutagenesis in the liverwort Marchantia polymorpha $\mathrm{L}$. Plant Cell Physiol 55:475-481. doi:10.1093/pcp/pcu014

Sun Z, Li N, Huang G, Xu J, Pan Y, Wang Z, Tang Q, Song M, Wang X (2013) Site-specific gene targeting using transcription activator-like effector (TALE)-based nuclease in Brassica oleracea. J Integr Plant Biol 55(11):1092-1103. doi:10.1111/jipb.12091

Tang L, González R, Dobrinski I (2015) Germline modification of domestic animals. Anim Reprod 12(1):93-104

The Arabidopsis Information Resource (TAIR) (2017) https://www. arabidopsis.org/portals/nomenclature/namerule.jsp on http:// www.arabidopsis.org. Accessed 14 Feb 2017

Townsend JA, Wright DA, Winfrey RJ, Fu F, Maeder ML, Joung JK, Voytas DF (2009) High-frequency modification of plant genes using engineered zinc-finger nucleases. Nature 459(7245):442445. doi: $10.1038 /$ nature 07845

Treen N, Yoshida K, Sakuma T, Sasaki H, Kawai N, Yamamoto T, Sasakura Y (2014) Tissue-specific and ubiquitous gene knockouts by TALEN electroporation provide new approaches to investigating gene function in Ciona. Development 141(2):481487. doi:10.1242/dev.099572

Waaijers S, Boxem M (2014) Engineering the Caenorhabditis elegans genome with CRISPR/Cas9. Methods 68:381-388. doi:10.1016/j.ymeth.2014.03.024

Wain HM, Bruford EA, Lovering RC, Lush MJ, Wright MW, Povey S (2002) Guidelines for human gene nomenclature. Genomics 79(4):464-470

Wan H, Feng C, Teng F, Yang S, Hu B, Niu Y, Xiang AP, Fang W, Ji W, Li W, Zhao X, Zhou Q (2015) One-step generation of p53 gene biallelic mutant Cynomolgus monkey via the CRISPR/Cas system. Cell Res 25(2):258-261. doi:10.1038/cr.2014.158

Wang T, Hong Y (2014) Direct gene disruption by TALENs in medaka embryos. Gene 543(1):28-33. doi:10.1016/j gene.2014.04.013

Wang Y, Cheng X, Shan Q, Zhang Y, Liu J, Gao C, Qiu JL (2014a) Simultaneous editing of three homoeoalleles in hexaploid bread wheat confers heritable resistance to powdery mildew. Nat Biotechnol 32(9):947-951. doi:10.1038/nbt.2969

Wang Y, Fan N, Song J, Zhong J, Guo X, Tian W, Zhang Q, Cui F, Li L, Newsome PN, Frampton J, Esteban MA, Lai L (2014b) Generation of knockout rabbits using transcription activator-like effector nucleases. Cell Regen 3(1):3. doi:10.1186/2045-9769-3-3

Watanabe T, Ochiai H, Sakuma T, Horch HW, Hamaguchi N, Nakamura T, Bando T, Ohuchi $\mathrm{H}$, Yamamoto T, Noji S, Mito T (2012) Non-transgenic genome modifications in a hemimetabolous insect using zinc-finger and TAL effector nucleases. Nat Commun 3:1017. doi:10.1038/ncomms2020

Wendt T, Holm PB, Starker CG, Christian M, Voytas DF, Brinch-Pedersen H, Holme IB (2013) TAL effector nucleases induce mutations at a pre-selected location in the genome of primary barley transformants. Plant Mol Biol 83(3):279-285. doi:10.1007/ s11103-013-0078-4

Wolfs JM, Hamilton TA, Lant JT, Laforet M, Zhang J, Salemi LM, Gloor GB, Schild-Poulter C, Edgell DR (2016) Biasing genome-editing events toward precise length deletions with an RNA-guided TevCas9 dual nuclease. Proc Natl Acad Sci USA 113(52):14988-14993. doi:10.1073/pnas.1616343114

WormBase (2017). WormMine WS257 intermine data mining platform for C. elegans and related nematodes. http://im-257.wormbase.org. Accessed 6 Apr 2017

Wu H, Wang Y, Zhang Y, Yang M, Lv J, Liu J, Zhang Y (2015) TALE nickase-mediated SP110 knockin endows cattle with increased resistance to tuberculosis. Proc Natl Acad Sci USA 112(13):E1530-E1539. doi:10.1073/pnas.1421587112

Wu Y, Zhong W, Cui N, Johnson CM, Xing H, Zhang S, Jiang C (2016) Characterization of Rett Syndrome-like phenotypes in Mecp2-knockout rats. J Neurodev Disord 8:23. doi:10.1186/ s11689-016-9156-7

Xu H, O'Brochta DA (2015) Advanced technologies for genetically manipulating the silkworm Bombyx mori, a model Lepidopteran insect. Proc Biol Sci. doi:10.1098/rspb.2015.0487

Yano A, Guyomard R, Nicol B, Jouanno E, Quillet E, Klopp C, Cabau C, Bouchez O, Fostier A, Guiguen Y (2012) An immune-related gene evolved into the master sex-determining gene in rainbow trout, Oncorhynchus mykiss. Curr Biol 22(15):1423-1428. doi:10.1016/j.cub.2012.05.045

Yates B, Braschi B, Gray K, Seal R, Tweedie S, Bruford E (2017) Genenames.org: the HGNC and VGNC resources in 2017. Nucleic Acids Res 45(D1):D619-D625. doi:10.1093/nar/ gkw1033

Zhang D, Glotzer M (2015) The RhoGAP activity of CYK-4/ $\mathrm{MgcRacGAP}$ functions non-canonically by promoting RhoA activation during cytokinesis. Elife. doi:10.7554/eLife.08898

Zhang F, Maeder ML, Unger-Wallace E, Hoshaw JP, Reyon D, Christian M, Li X, Pierick CJ, Dobbs D, Peterson T, Joung JK, Voytas DF (2010) High frequency targeted mutagenesis in Arabidopsis thaliana using zinc finger nucleases. Proc Natl Acad Sci USA 107(26):12028-12033. doi:10.1073/pnas.0914991107

Zhang Y, Zhang F, Li X, Baller JA, Qi Y, Starker CG, Bogdanove AJ, Voytas DF (2013) Transcription activator-like effector nucleases enable efficient plant genome engineering. Plant Physiol 161(1):20-27. doi:10.1104/pp.112.205179

Zhang L, Jia R, Palange NJ, Satheka AC, Togo J, An Y, Humphrey M, Ban L, Ji Y, Jin H, Feng X, Zheng Y (2015) Large genomic 
fragment deletions and insertions in mouse using CRISPR/ Cas9. PLoS ONE 10(3):e0120396. doi:10.1371/journal. pone. 0120396

Zhang B, Yang X, Yang C, Li M, Guo Y (2016a) Exploiting the CRISPR/Cas9 system for targeted genome Mutagenesis in Petunia. Sci Rep 6:20315. doi:10.1038/srep20315

Zhang X, Wang L, Wu Y, Li W, An J, Zhang F, Liu M (2016b)

Knockout of myostatin by Zinc-finger nuclease in sheep fibroblasts and embryos. Asian Australas J Anim Sci 29(10):15001507. doi:10.5713/ajas.16.0130
Zhang Z, Mao Y, Ha S, Liu W, Botella JR, Zhu JK (2016c) A multiplex CRISPR/Cas9 platform for fast and efficient editing of multiple genes in Arabidopsis. Plant Cell Rep 35(7):15191533. doi:10.1007/s00299-015-1900-Z

Zhang JP, Li XL, Li GH, Chen W, Arakaki C, Botimer GD, Baylink D, Zhang L, Wen W, Fu YW, Xu J, Chun N, Yuan W, Cheng T, Zhang XB (2017) Efficient precise knockin with a double cut HDR donor after CRISPR/Cas9-mediated doublestranded DNA cleavage. Genome Biol 18(1):35. doi:10.1186/ s13059-017-1164-8 